www.periodicos.ufpe.br/revistas/jhrs

\title{
Detection of changes of the soil use and vegetation in the low San Francisco
}

\author{
Douglas A. de O. Silva ${ }^{*}$, Frederico A. C. Lins, Jhon Lennon B. da Silva*, Landson C. da Silva ${ }^{* * *}$, Geber B. de A. \\ Moura $^{* * *}$, Pabrício M. O. Lopes ${ }^{* *}$
}

"Master in Agricultural Engineering, Department of Agricultural Engineering, Federal Rural University of Pernambuco

(UFRPE), Recife-PE, Brazil. E-mail: douglasalbertosilva@ hotmail.com, frederico_acl@ hotmail.com, jhonlennoigt@hotmail.com (Corresponding Author)

**Agronomy Student, Agronomy Department, UFRPE, Recife-PE, Brazil. E-mail: landson.14@gmail.com

${ }^{* * *} \mathrm{Ph} . \mathrm{D}$. in Oceanography, Agronomy Department, Full Professor of UFRPE, Recife-PE, Brazil. E-mail: geber@ depa.ufrpe.br

${ }_{* * * * *}$ Ph.D. in Remote Sensing, Agronomy Department, Assintant Professor of UFRPE, Recife-PE, Brazil. E-mail: pabriciope@gmail.com

Received 6 August 2019, accepted 28 September 2019

\begin{abstract}
The quantification and spatialization of environmental degradation is an essential element in the planning of agricultural activities and in the management of the water and natural resources in the semiarid. Thus, the detection of changing land use conditions is necessary for understand with more accurately the dynamics of the different types of soil coverage. Remote sensing techniques make it possible to evaluate this type of environmental monitoring in a practical and efficient manner, and low operating cost in a short time. The objective of this study was to monitor and evaluate the environmental changes caused about the Caatinga vegetation coverage by remote sensing using satellite images in the municipality of Petrolina, semiarid region of Pernambuco state. The study was developed using two Landsat-8 satellite images, processed using SEBAL algorithm steps, in the development of thematic maps of the surface biophysical parameters. The maps expressed the spatial distribution of the albedo parameters and surface temperature, and of the NDVI and SAVI vegetation indices, which served for highlight the dynamics of environmental changes in the Caatinga natural environment of semiarid region. The results showed increased of the albedo and surface temperature when there was a decrease in vegetation indices. This behavior was mainly favored by the region's dry season, which coincides with the satellite's days of passage. The biophysical parameters are effective in the spatial monitoring of semiarid regions, highlighting the spatial variability of the soil uses, identifying possibly degraded areas. Remote sensing environmental monitoring is a viable alternative for mitigate environmental changes caused by anthropogenic actions and drought events.

Keywords: Caatinga, degradation, drought.
\end{abstract}

\section{Introduction}

The environmental changes in the Northeast region of the Brazil are connected to several factors, mainly to the anthropic activities practiced in a marked way in these regions due to the environmental impacts as, deforestation, burning, inadequate management of irrigated agriculture and intensive farming practices. Drought exceptionally, for example, is the main aggravating condition of the semiarid regions in Northeastern Brazil. Evaporative demand in the semiarid tends to be higher than rainfall, favoring a marked water deficit, in which it is possible to observe high rates of potential evapotranspiration, showing regions favorable to environmental degradation, especially in dry seasons (Palácio et al., 2013; Gutiérrez et al., 2014; Marengo et al., 2016; Marengo et al., 2018; Mariano et al., 2018).
Obtaining surface degradation data has an important role in agriculture. This is a basic variable in studies related to the detection of changes in large areas. Regional scale surface monitoring can be performed using remote sensing techniques, which allow to analyze of the relationship between spatial patterns of vegetation and changes in radiation balance and of the surface energy fluxes (Fausto et al., 2014). With the application of algorithms, such as the Surface Energy Balance Algorithm for Land (SEBAL), it is possible the estimate soil surface changes from biophysical indices, highlighting vegetation index, albedo, temperature and surface radiation balance (Bastiaanssen et al., 1998a, Bastiaanssen et al., 1998b; Bastiaanssen, 2000; al., 2002; Bastiaanssen, 2005).

The detecting soil use change is crucial for better understanding the dynamics of soil coverage change (Turner e Ruscher, 2004). Currently the 
satellite data on land resources are applicable for change detection studies in the soil use (Yuan et al., 2005). Remote sensing data applications allow study about the changes in the land coverage in spatial and temporal scale, at low cost and with better accuracy (Kachhwala, 1985). In this context, SEBAL has several functionalities, such as in the monitoring and detecting changes in soil use and land coverage, as well as possible regional and global environmental impacts (Oliveira et al., 2012; Nascimento et al., 2014; Fausto et al., 2014).

In this aspect, the choice of the study area was based in the essentiality of research about to possible environmental changes through the aforementioned biophysical indicators. These which allow a practical and efficient environmental monitoring in the order to ensure planning measures and even measures to reverse the degradation of the natural environment Caatinga for soil conservation in semiarid region.

In this context, mainly targeting the lack of study in this regard in the semiarid, this study aimed to monitor and evaluate the standards of environmental changes caused about the vegetation of Caatinga and other land uses through remote sensing techniques, with the use of Landsat-8 satellite images in a semiarid region in the low São Francisco, in the municipality of Petrolina, Pernambuco.

\section{Materials and methods}
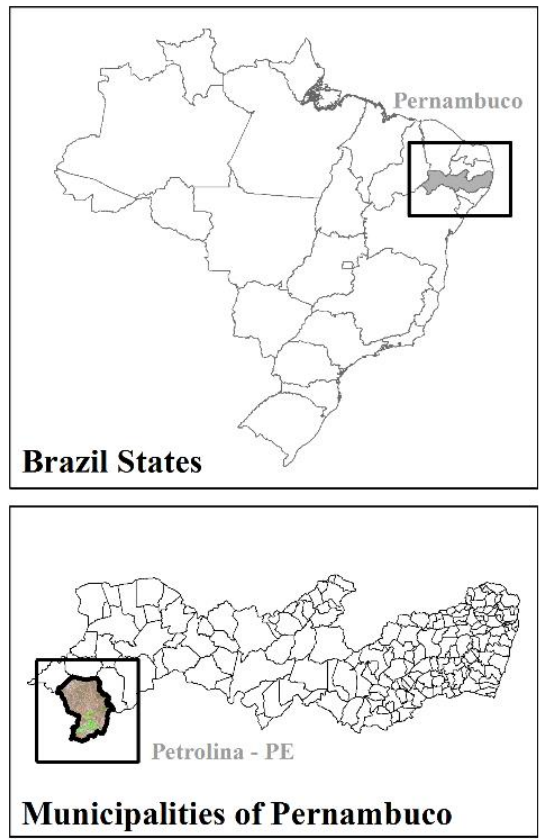

Geographic Coordinate System DATUM: WGS84 - Zone 24 S

\section{Study Location Area}

The area of the present study comprises the municipality of Petrolina, belonging to the São Francisco Pernambuco Mesoregion, Pernambuco state, semiarid region of the Northeast Brazil. Petrolina is specifically located at the following geographical coordinates, between the parallels of $8^{\circ}$ $41^{\prime} 30^{\prime \prime} \mathrm{S}$ and $9^{\circ} 30^{\prime} 0.0^{\prime \prime} \mathrm{S}$, and between the meridians of $40^{\circ} 8^{\prime} 30^{\prime \prime} \mathrm{W}$ and $41^{\circ} 0^{\prime} 30^{\prime \prime} \mathrm{W}$, and altitude of $365,5 \mathrm{~m}$. The climate classification, according to Köppen, is of the BSw'h' type (hot and dry semiarid), with the occurrence of two welldefined seasons during the year, dry season (between May to October) and rainy season (between November to April). The region has an average annual rainfall of $431.8 \mathrm{~mm}$, with rain concentrated in a single period of the year and with an irregular spatial distribution. The average annual temperature is around of $26.4{ }^{\circ} \mathrm{C}$ and relative air humidity around 58\% (Silva et al., 2005; Alvares et al., 2013).

Figure 1 shows the study area, municipality of Petrolina-PE, through of an image of the Landsat- 8 OLI sensor satellite, which highlights the Caatinga vegetation (brown tonality pixel) and irrigated areas of the region (green tonality pixel), as also highlights the automatic weather station of the National Institute of Meteorology (INMET). The satellite image presented was georeferenced by the DATUM Geographic Coordinate System: WGS84 - Zone 24 S.

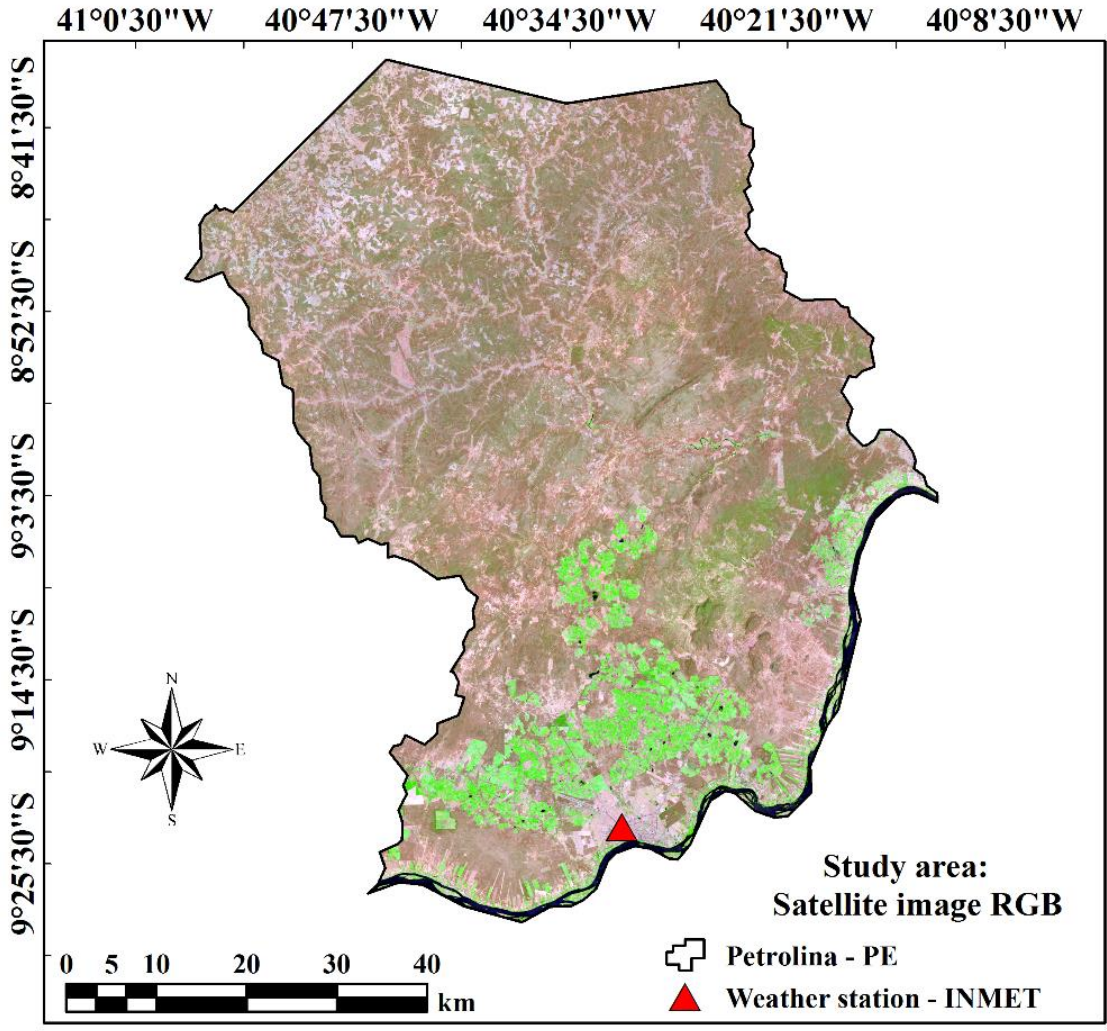

Figure 1 - Spatial map of location of the study area, Petrolina, Pernambuco, Brazil. Satellite image Landsat-8 OLI sensor in natural color in RGB composite-432. 


\section{Surface weather data}

Through of INMET weather station, located in the study area (Figure 1), it was possible to use complementary surface data along with satellite images, which were essential in calibration and correction of the multispectral bands used in the present study.

Table 1 presents the temporal variability of rainfall recorded by the INMET weather station, aiming to more accurately assess the possible environmental changes in the soil uses of the semiarid region.

Table 2 presents the input data in the instant of satellite passage: sequential day of year (SDY), local hour of passage, instantaneous air temperature $\left(\mathrm{T}_{\mathrm{ar}},{ }^{\circ} \mathrm{C}\right)$, instantaneous relative humidity $(\mathrm{RH}, \%)$ and the instantaneous atmospheric pressure of air $\left(\mathrm{P}_{\mathrm{o}}\right.$, $\mathrm{kPa})$.

Table 1 - Monthly rainfall in the semiarid region of Petrolina-PE.

\begin{tabular}{cccc}
\hline \multirow{2}{*}{ Mês } & \multicolumn{3}{c}{ Monthly rainfall (mm) } \\
\cline { 2 - 4 } & Year 2013 & Year 2014 & Year 2015 \\
\hline January & 30 & 28.6 & 12 \\
February & 0.0 & 37.5 & 34.6 \\
March & 54.8 & 56.7 & 27.1 \\
April & 33.8 & 179.8 & 78.2 \\
May & 1.8 & 1.6 & 0.8 \\
June & 6.8 & 1.3 & 2.4 \\
July & 13.6 & 26.3 & 2.6 \\
August & 4.6 & 2.4 & 0.1 \\
September & 0.4 & 7.2 & 0.0 \\
October & 0.0 & 0.0 & 13.7 \\
November & 33.6 & 91.4 & 0.0 \\
December & 155 & 47.9 & 3.6 \\
\hline Total (mm) & 334.4 & 480.7 & 175.1 \\
\hline
\end{tabular}

Table 2. Input data and surface weather variables in the instant of the satellite passage in automatic weather station.

\begin{tabular}{ccccccc}
\hline Satellite & Image date & SDY & Passage hour & $\mathrm{T}_{\mathrm{ar}}\left({ }^{\circ} \mathrm{C}\right)$ & $\mathrm{RH}(\%)$ & $\mathrm{P}_{\mathrm{o}}(\mathrm{kPa})$ \\
\hline Landsat- 8 & $10 / 05 / 2013$ & 278 & 09h36min & 30.34 & 39.25 & 97.20 \\
OLI Sensor & $10 / 27 / 2015$ & 300 & 09h40min & 29.34 & 47.00 & 97.41 \\
\hline
\end{tabular}

\section{Orbital data}

The study was accomplished using two images of the Landsat-8 satellite of Operational Land Images/Thermal Infrared Sensor (OLI/TIRS) sensors, dated 10/05/2013 and 10/27/2015. The orbital images were provided by the National Aeronautics and Space Administration (NASA) space agency, acquired in the United States Geological Survey (USGS) website. Landsat-8 OLI/TIRS multispectral bands were used: $2 ; 3 ; 4 ; 5 ; 6 ; 7$ (30 m spatial resolution) and thermal band 10 (100 m spatial resolution).

The images were processed by ERDAS IMAGINE $^{\circledR}$ 9.1 Software, with the implementation of the Surface Energy Balance Algorithm for Land (SEBAL) algorithm. In the algorithm, the images were processed through spatial mathematical modeling, where the albedo biophysical parameters and surface temperature and vegetation indices were estimated. Steps such as georeferencing of the multispectral bands and the atmospheric correction process were performed using the Fast Line-of-sight Atmospheric Analysis of Spectral Hypercubes (FLAASH) (Felde et al., 2003). Thematic maps of the biophysical indices were processed by $\operatorname{ArcGIS}^{\circledR}$ 10.2.2 Software.

\section{Processing Steps (SEBAL Algorithm)}

Equation 1 presents the spectral radiance determined on each Landsat-8 OLI sensor multispectral band (where the gray levels of the images were converted to radiance). Radiance ( $\mathrm{Lb}, \mathrm{W}$ m-2 sr-1 $\mu \mathrm{m}-1)$ was estimated from additive and multiplicative terms (Chander et al., 2009; Silva et al., 2016). The terms are radiometric coefficients that were used for the conversion process, made available by NASA along with the images collected for the present study (NASA/USGS, 2018).

$$
\mathrm{L}_{\mathrm{b}}=\mathrm{Add}_{\mathrm{rad}}+\text { Mult }_{\mathrm{rad}} \times \mathrm{ND}_{\mathrm{b}}
$$

On what:

$\operatorname{Add}_{\mathrm{rad}} \mathrm{b}$ is the term additive; Mult rad $\mathrm{b}$ the multiplicative term (referring to spectral radiance); $\mathrm{ND}_{\mathrm{b}}$ is the intensity of each pixel and band (where for the Landsat- 8 satellite, values are between 0 and 65,365 , high quality digital information). 
Equation 2 presents the determination of the monochrome reflectance $\left(\mathrm{r}_{\mathrm{b}}, \mathrm{W} \mathrm{m}^{-2} \mathrm{sr}^{-1} \mu \mathrm{m}^{-1}\right)$ in each band of the Landsat-8 OLI satellite, also highlighting the utilization of calibration values by the additive and multiplicative terms provided by NASA/USGS (Chander et al., 2009; Silva et al., 2016; NASA/USGS, 2018).

$$
\mathrm{r}_{\mathrm{b}}=\frac{\left(\mathrm{Add}_{\mathrm{ref}}+\text { Mult }_{\mathrm{ref}} \times \mathrm{ND}_{\mathrm{b}}\right)}{\cos \theta \times \mathrm{d}_{\mathrm{r}}}
$$

On what:

$\operatorname{Add}_{\text {ref }} \mathrm{b}$ is the term additive; Multref b is the multiplicative term (referring to reflectance).

In Equation 3, as a complement to the previous equation, it was possible to determine the square of the ratio between the average and instantaneous distances between the earth and the sun on a given day of the year (dr), according to Iqbal (1983).

$$
\mathrm{d}_{\mathrm{r}}=1+0.033 \times \cos \left(\frac{\mathrm{SDY} \times 2 \times \pi}{365}\right)
$$

On what:

SDY is the sequential day of the year, with the cos function argument in radians.

Thus, in the same sense, the determination of the solar zenith angle $(\theta)$ can be observed in Equation 4 , this is determined from the sun elevation angle (E), in degrees.

$$
\theta=\cos \left(\frac{\pi}{2}-E\right)=\operatorname{sen}(E)
$$

Through the radiance and reflectance processing steps, it was followed with the determination of the planetary albedo $\left(\alpha_{\text {toa }}\right)$, this without atmospheric correction, using weight coefficient values according to studies in semiarid region de Silva et al. (2016) and also in accordance with recommendations of the NASA/USGS (2018), Equation 5.

$$
\begin{gathered}
\alpha_{\text {toa }}=0.300 \times \mathrm{r}_{2}+0.277 \times \mathrm{r}_{3}+0.233 \times \mathrm{r}_{4}+ \\
0.143 \times \mathrm{r}_{5}+0.036 \times \mathrm{r}_{6}+0.012 \times \mathrm{r}_{7}
\end{gathered}
$$

On what:

The values: $0.300 ; 0.277 ; 0.233 ; 0.143 ; 0.036$ and 0.012 are the weights for each Landsat-8 OLI sensor band; $r_{2}, r_{3}, r_{4}, r_{5}, r_{6}$ and $r_{7}$ are the reflectance's of each OLI sensor bands, respectively (Silva et al., 2016).

Thus, with the determination of the previous parameter, it was possible to estimate one of the main objectives of the study which is the surface albedo (asup), with atmospheric correction (Equation 6), estimated mainly according to research in the semiarid regions of Brazil (Silva et al., 2005; Bezerra et al., 2014; Silva et al., 2016; Silva et al., 2019).

$$
\alpha_{\text {sup }}=\frac{\alpha_{\text {toa }-} \alpha_{\text {atm }}}{\tau_{\text {sw }}^{2}}
$$

On what:

$\alpha_{\text {atm }}$ is the reflectance of the atmosphere (Allen et al., 2002); $\tau_{\mathrm{sw}}$ is the atmospheric transmissivity highlighted in Equation 7 (Bezerra et al., 2014; Silva et al., 2016).

$$
\begin{aligned}
& \tau_{\mathrm{sw}}=0.35+0.627 \times \\
& \exp \left[\frac{-0.00146 \times \mathrm{P}_{\mathrm{o}}}{\mathrm{K}_{\mathrm{t}} \times \cos \theta}-0.075\left(\frac{\mathrm{W}}{\cos \theta}\right)^{0.4}\right]
\end{aligned}
$$

On what:

$\mathrm{P}_{\mathrm{o}}$ is the atmospheric pressure $(\mathrm{kPa})$ measured at the INMET weather station; $K_{t}$ is the atmosphere turbidity coefficient (using 1.0) for clear and clear skies (Allen et al., 2007); W is the precipitable water $(\mathrm{mm})$, determined from the relative humidity of the air, according to Equation 8.

$$
\mathrm{W}=0.14 \times \mathrm{e}_{\mathrm{a}} \times \mathrm{P}_{\mathrm{o}}+2.1
$$

On what:

$\mathrm{e}_{\mathrm{a}}$ is the actual water vapor pressure $(\mathrm{kPa})$ determined according to Equation 9.

$$
\mathrm{e}_{\mathrm{a}}=\frac{\mathrm{UR} \times \mathrm{e}_{\mathrm{s}}}{100}
$$

On what:

$\mathrm{e}_{\mathrm{s}}$ is the water vapor saturation pressure $(\mathrm{kPa})$ determined according to Equation 10.

$$
\mathrm{e}_{\mathrm{s}}=0.6108 \times \exp \left(\frac{17.27 \times \mathrm{T}_{\mathrm{ar}}}{237.3+\mathrm{T}_{\mathrm{ar}}}\right)
$$

On what:

$\mathrm{T}_{\mathrm{ar}}$ is the air temperature $\left({ }^{\circ} \mathrm{C}\right)$.

Then, according to Equation 11, the Normalized Difference Vegetation Index (NDVI) was determined. The NDVI index was determined using Landsat-8 OLI reflective bands (Accioly et al., 2002; Allen et al., 2002; Bezerra et al., 2014; Silva et al., 2018).

$$
\mathrm{NDVI}=\frac{\mathrm{r}_{\mathrm{b} \text { IV }}-\mathrm{r}_{\mathrm{bV}}}{\mathrm{r}_{\mathrm{b} \text { IV }}+\mathrm{r}_{\mathrm{bV}}}
$$

On what:

$\mathrm{r}_{\mathrm{b} \text { IV }}$ and $\mathrm{r}_{\mathrm{b}} \mathrm{v}$ are to reflective bands 5 and 4 of the Landsat-8 OLI sensor satellite. 
At the same time, using the same NDVI multispectral bands, the Soil Adjusted Vegetation Index (SAVI) was also determined (Equation 12). However, it is an index that has an adjustment factor for soil conditions, that is, it is a parameter in which it minimizes soil effects and allows observing similar conditions with the current reality of vegetation about the study area (Huete, 1998).

$$
\operatorname{SAVI}=\frac{(1+\mathrm{L}) \times\left(\mathrm{r}_{\mathrm{bIV}}-\mathrm{r}_{\mathrm{bV}}\right)}{\left(\mathrm{L}+\mathrm{r}_{\mathrm{bIV}}+\mathrm{r}_{\mathrm{bV}}\right)}
$$

On what:

$\mathrm{L}$ is the soil adjustment constant (value 0.5), which indicates an area with intermediate Caatinga vegetation coverage, typical of the semiarid (Huete, 1988; Allen et al., 2007; Silva e Galvíncio, 2012).

Through of the SAVI vegetation index was obtained leaf area index (LAI, Equation 13) measured in $\mathrm{m}^{2} \mathrm{~m}^{-2}$. The LAI is an important parameter for determining the emissivity in the thermal band spectral domain (Equation 14), which is essential for surface temperature estimation (Allen et al., 2007).

$$
\mathrm{LAI}=-\frac{\ln \left(\frac{0.69-\mathrm{SAVI}}{0.59}\right)}{0.91}
$$

The thermal band domain emissivity was estimated by the leaf area index, according to Equation 14 (Allen et al., 2002).

$$
\varepsilon_{\mathrm{NB}}=0.97+0.0033 \times \mathrm{LAI}
$$

Surface temperature $\left(\mathrm{T}_{\mathrm{s}}\right)$ was initially determined in Kelvin, then transformed into degrees Celsius, Equation 15 (Allen et al., 2002).

$$
\mathrm{T}_{\mathrm{s}}=\frac{\mathrm{K}_{2}}{\left(\frac{\varepsilon_{\mathrm{NB}} \times \mathrm{K}_{1}}{\mathrm{~L}_{\mathrm{b}}}+1\right)}
$$

On what:

$\mathrm{K}_{1}$ and $\mathrm{K}_{2}$ are calibration constants for the thermal band 10 of the Landsat- 8 TIRS sensor satellite $\left(\mathrm{K}_{1}=\right.$ $774.89 \mathrm{~W} \mathrm{~m}^{-2} \mathrm{sr}^{-1} \mu \mathrm{m}^{-1}$ and $\mathrm{K}_{2}=1321.08 \mathrm{~K}$ ). The coefficients were also suggested by NASA/USGS (NASA/USGS, 2018).

Thus, environmental changes in the Petrolina-PE region, be these changes due to anthropic actions and/or local climate changes, such as drought events, were analyzed and monitored through the determination of terrestrial surface thematic maps, observed and spatially evaluated.

\section{Results and discussion}

Satellite spatial environmental monitoring through the processing and development of the terrestrial surface thematic maps highlight consistent results from the study area, presenting similar response patterns with the current literature. The behavior of the maps warns of the changing conditions of Caatinga natural vegetation over time.

Figure 2 illustrates the surface albedo spatialization through of thematic maps of the municipality of Petrolina-PE, semiarid region of the Brazil. From the spatial monitoring of this biophysical parameter, such as were observed the highest values of albedo about the south region of the orbital images (Figures 2A and 2B, red tonality pixel), the banks of the São Francisco river, as well as in the urban area of the municipality of Petrolina, as expected. However, it is noteworthy that the river banks, due to the high values, can be in degradation process and/or already with degraded areas, since this parameter is an important indicator of areas in this sense, identifying the existence of environmental changes (Silva et al., 2005; Silva et al., 2016; Silva et al., 2019).

The lowest values of the albedo are represented in the blue tonality, where the extension of the São Francisco river is located, and also in areas with a strong presence of soil surface moisture and surrounding vegetation moisture. In general, the areas with Caatinga vegetation coverage were observed albedo values between 0.08 and 0.15 ; in urban areas, degraded and/or exposed soil between 0.28 and 0.50 (Figure 2). Arraes et al. (2012) studying the dynamics of the energy balance in the semiarid region of Ceará, detected an increasing tendency of albedo over anthropic areas, with values between 0.11 and 0.19 .

Bezerra et al. (2014) evaluated the spatiotemporal dynamics of biophysical parameters such as albedo, NDVI, SAVI and surface temperature, also in Caatinga area, semiarid region, by remote sensing, and highlighted that the albedo it's directly associated with the use and soil occupation and also to the Caatinga vegetation coverage, finding the highest values of the albedo in the dry period and about exposed soil areas, corroborating the present research.

Figure 3 illustrates the spatialization of the NDVI vegetation index. Their highest positive values were observed in dark blue (0.58 - 1.00), followed by the greener tonality pixel, which express areas with more intense vegetation and mainly, for the most part, areas of agricultural cultivation, as observed in the south-central and south regions of the maps, located near the rivers and reservoirs of the semiarid region, while it was also observed for some excerpts the preservation of the forest on the river banks. 

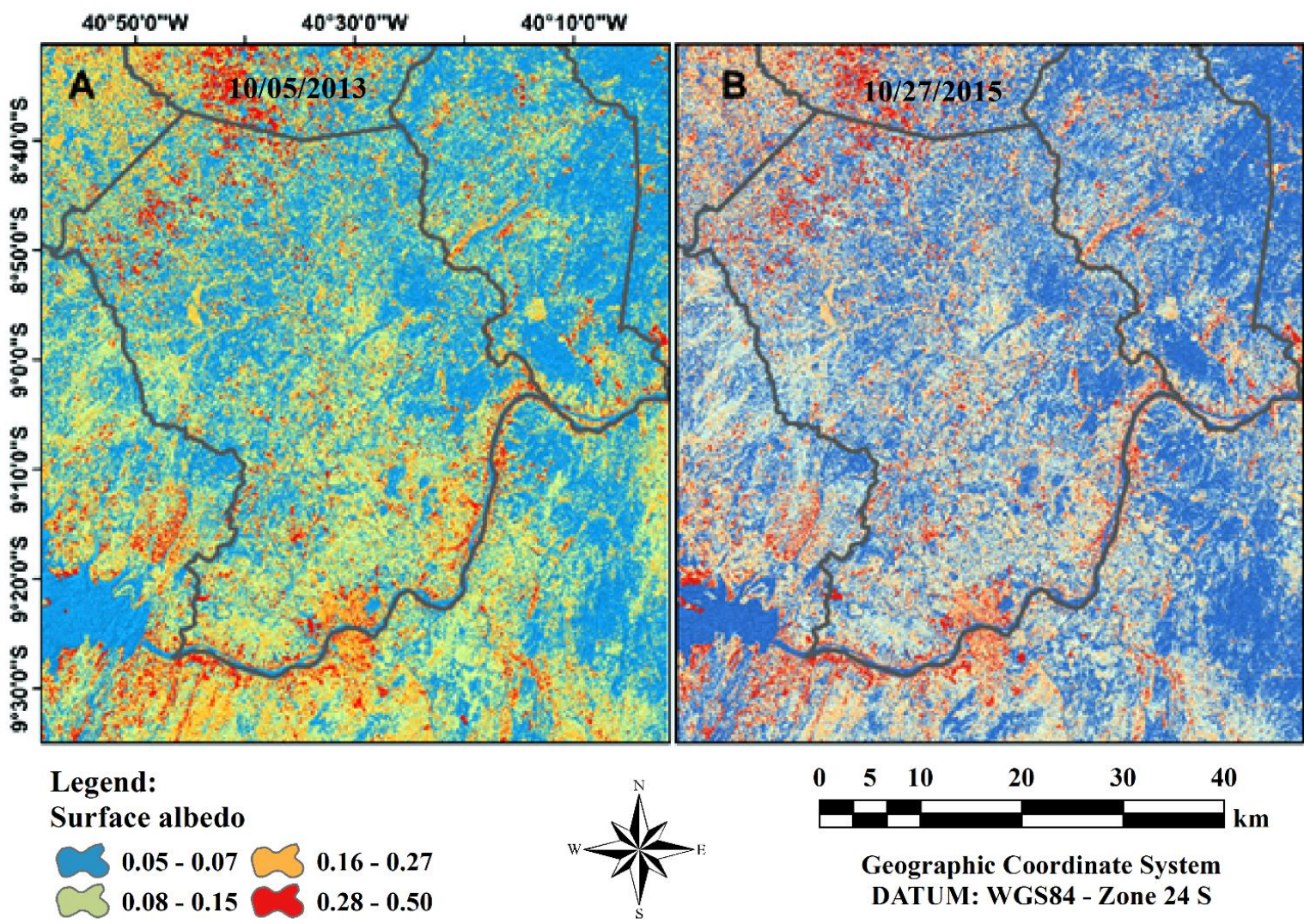

Geographic Coordinate System DATUM: WGS84 - Zone 24 S

Figure 2 - Thematic map of the spatial distribution pattern of the surface albedo in the semiarid region of the municipality of Petrolina-PE, in the days of passage of the Landsat-8 satellite: 10/05/2013 (A) and 10/27/2015 (B).

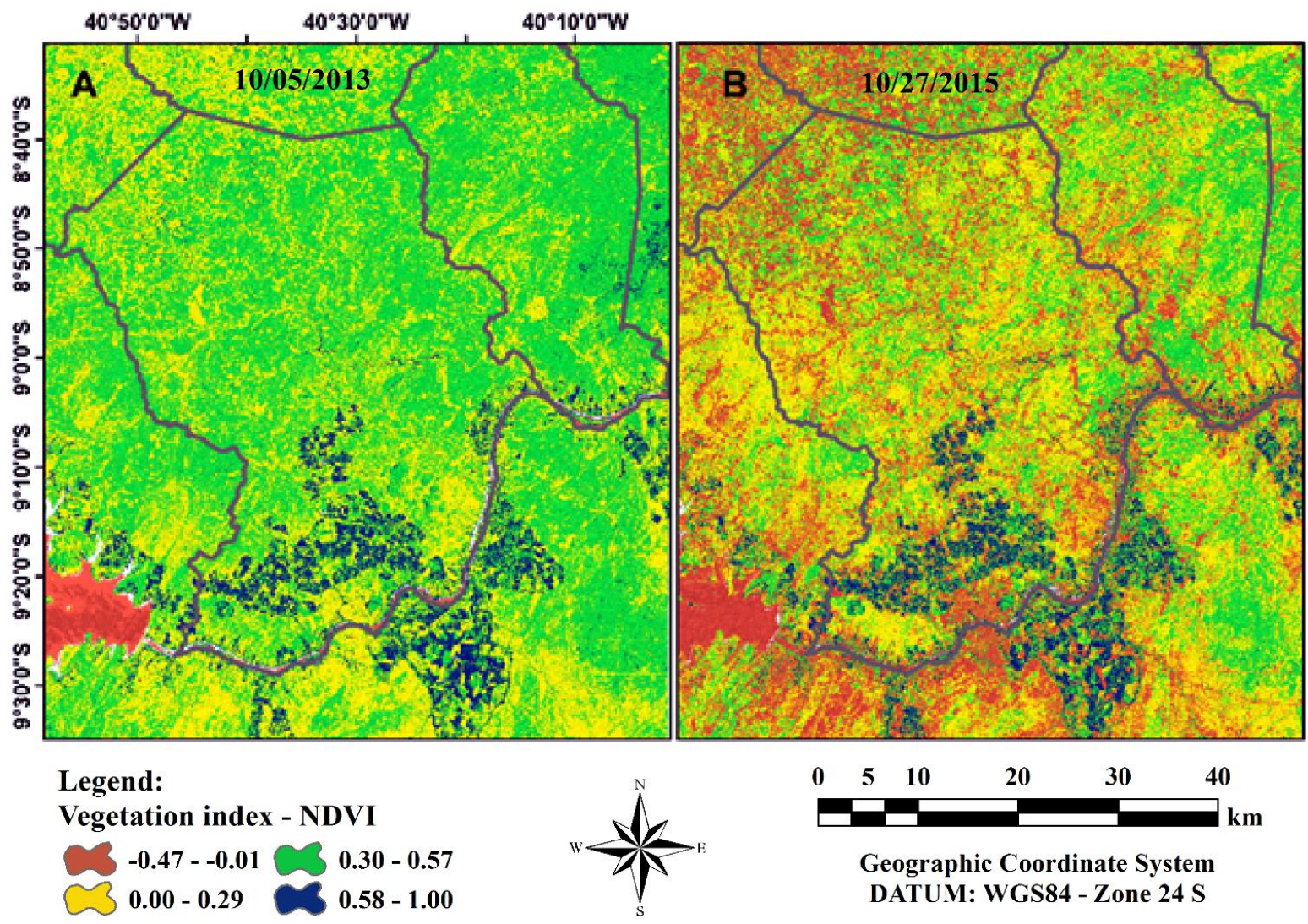

Figure 3 - Thematic map of the spatial distribution pattern of the NDVI vegetation index in the semiarid region of the municipality of Petrolina-PE, in the days of passage of the Landsat-8 satellite: 10/05/2013 (A) and 10/27/2015 (B). 
The lowest NDVI values were observed for areas with darker shades of brown pixel colors $(-0.47$ to -0.01), expressing negative numbers, which specifically comprise the water body areas of the region (Figure 3). With that, the thematic map of 10/05/2013 (Figure 3A) presented higher humidity conditions among the existing vegetation in the region. Rodrigues et al. (2009) stressed that the high values of the NDVI vegetation index are directly related to the events and rainy seasons in the semiarid, which passes to influence the vegetation, with leaf canopy resilience, consequently increasing the plant biomass immediately. Bezerra et al. (2014) and Silva et al. (2019) confirmed this situation, and also, the authors found similar results to the present research, highlighting the importance of the using the remote sensing technique, which uses fast and efficient performance, favoring decision making and reversal measures for the sustainable management of Caatinga natural environment.

Figure 4 illustrates the spatialization of the SAVI vegetation index. This index had a good representation of the vegetative canopy, similar to those observed in the NDVI, but more clearly due to the soil correction factor (Silva e Galvíncio, 2012).

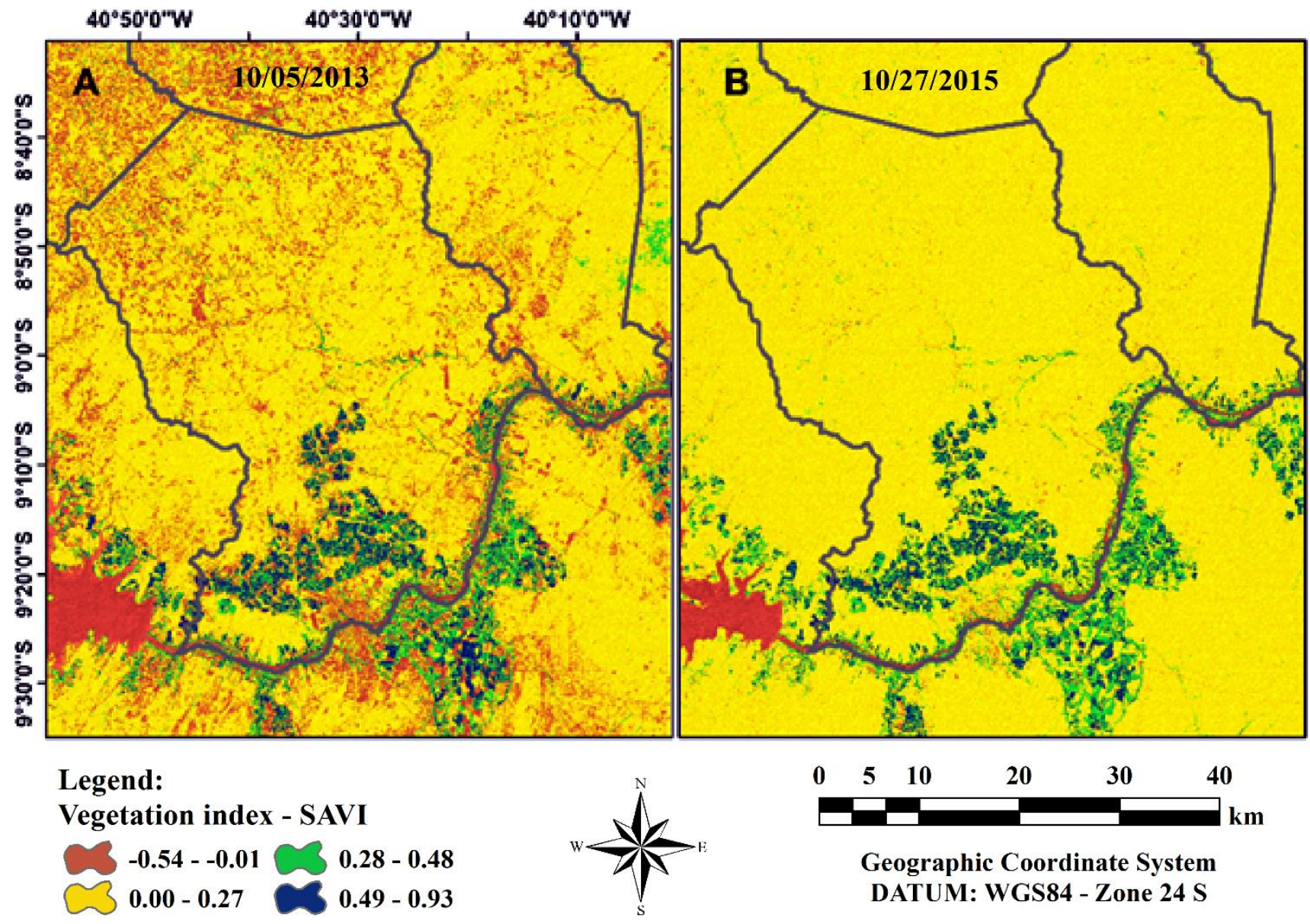

Figure 4 - Thematic map of the spatial distribution pattern of the SAVI vegetation index in the semiarid region of the municipality of Petrolina-PE, in the days of passage of the Landsat-8 satellite: 10/05/2013 (A) and 10/27/2015 (B).

The SAVI index portrayed more homogenized thematic maps in relation to the other indices, consistent with what basically represents the main vegetation condition in the semiarid region, showed low vegetation condition, highlighting the decline in vegetation cover due to the increase in water deficit, resulting behavior of the absence of rainfall. The SAVI thematic map in the day 10/05/2013 (Figure 4A) showed the lowest negative values (-0.54 to -0.01$)$ about the water bodies, in brown tones pixels (Figure 2). (Figure 2). The SAVI index had a similar behavior pattern to NDVI for all the soil uses. These results are according to those found by Souza (2014), which to analyzing the Caatinga vegetation coverage observed the lowest negative values about the water body class and the highest positive values about tree-shrub vegetation.

Drought events are the main causes of environmental imbalances in the semiarid regions of the Brazil, as consequence, many areas are susceptible to desertification and/or already desertified processes. Anthropic activities also 
contribute to the increase of degraded areas, mainly through inadequate management of agriculture, in line with practices such as burned and the forest deforestation for replacement by pasture vegetation. However, it is noteworthy that the natural Caatinga vegetation of the Brazilian semiarid regions, in the dry season, has a defense system, which is the leaf canopy recoil. And when in the rainy season the vegetation presents its fast resilience power.

Figure 5 illustrates the spatialization of surface temperature thematic maps. The lowest values for this parameter were found sobre the water bodies (11.16 to $26.51{ }^{\circ} \mathrm{C}$ ), as expected, represented by light tonality pixel, in blue band.

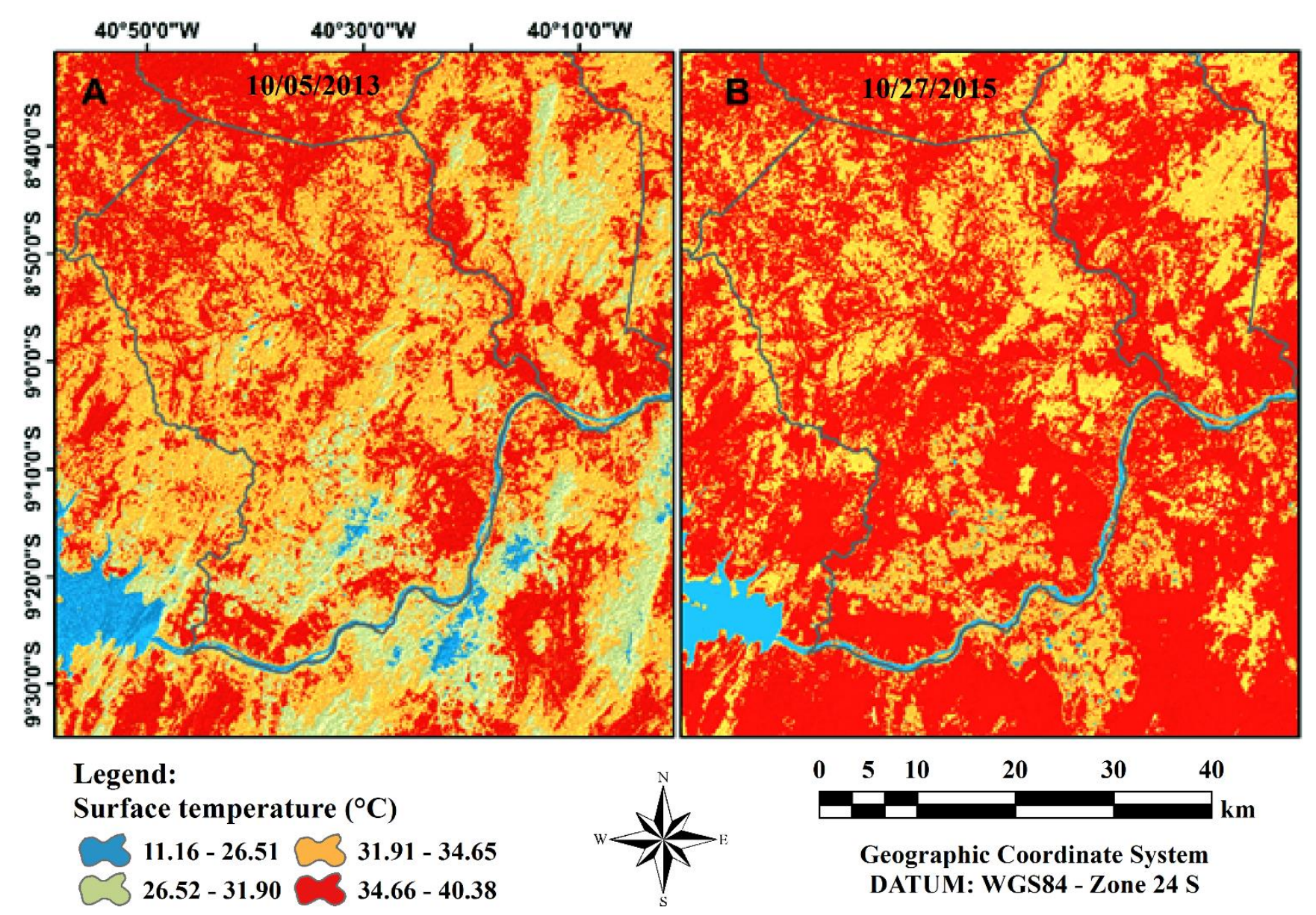

Figure 5 - Thematic map of the spatial distribution pattern of the surface temperature in the semiarid region of the municipality of Petrolina-PE, in the days of passage of the Landsat-8 satellite: 10/05/2013 (A) and 10/27/2015 (B).

The map of 10/27/2015 (Figure 5B) showed dark red tonality pixel, among the others, showing in general, which concentrates the highest temperatures $\left(40.38{ }^{\circ} \mathrm{C}\right.$, Figure 5). This fact, explained by the absence of precipitations preceding the passage of the satellite, besides being the dry season of the region. This is a epoch when semi-arid regions have high temperatures due to leaf canopy loss and increased water deficit, as already observed in the NDVI and SAVI vegetation indices previously.

In general terms, has been verified an increase in the temperature of the map areas on 10/27/2015 (Figure 5B). Especially in the areas near the banks of the São Francisco river, due to the high burned rates registered in the same year of 2015 . Actions and aggravating factors in this sense, deforestation, burned and severe drought events in the semiarid region of Pernambuco, it is possibly causing the environmental degradation of the soil and mainly altering the local microclimate of the region.

Silva et al. (2005) were able to estimate the surface temperature in areas with different types of soil use and occupation. The areas with the highest temperatures were exposed soil areas, ranging between 29.2 and $35.2{ }^{\circ} \mathrm{C}$. The increase of albedo and surface temperature, as well as the reduction of vegetation indices can be configured in areas possibly degraded and/or with larger susceptibility to degradation, mainly motivated by the drought phenomenon in the semiarid and, still, having their processes degrading processes accelerated by anthropic activities, in the intensification of agriculture activities.

However, to prove the main environmental impacts in the region, it is necessary to study more images over time, analyzing images both in the dry 
and rainy seasons, in the sense observe the quality of the vegetation year after year through these parameters already abovementioned, and also the need of the increase new terrestrial surface data, for example, degradation risk thematic maps for more accurately monitor the changing conditions of the natural environment.

The semiarid region of study presents different soil uses, especially areas of agricultural activities. With this, the intensification and pressure of agricultural activities and also of livestock in the region can favour the growth of exposed soil areas, staying still more evident in the dry seasons, which together contribute for the desertification processes.

\section{Conclusions}

Spatial analysis by orbital remote sensing (SEBAL) showed that changes in different soil uses can be possibly identified by spatial monitoring of surface biophysical parameters.

The albedo biophysical parameters and surface temperature had in the spatial analysis of the present study an analogous behavior pattern, as well as were contrary to the response patterns of the NDVI and SAVI vegetation indices.

The NDVI and SAVI vegetation indices were efficient in the environmental monitoring of vegetation in the semiarid region, and highlighted mainly the areas with irrigated agriculture management, located in the south-central and south regions of the thematic maps.

Satellite spatial environmental monitoring is of paramount importance in the planning and prior organization for decision making, directly favoring the sustainable management of the water and natural resources in the Brazilian semiarid.

\section{Acknowledgments}

The Federal Rural University of Pernambuco; Postgraduate Program in Agricultural Engineering; This study was financed in part by the Coordenação de Aperfeiçoamento de Pessoal de Nível Superior Brasil (CAPES) - Finance Code 001; NASA/USGS by the supply satellite images and the National Institute of Meteorology (INMET) by the supply of the surface weather data.

\section{References}

Accioly, L., Pachêco, A., Thomaz, C., Costa, C., Lopes, O.F., Oliveira, M.A.J., 2002. Relações empíricas entre a estrutura da vegetação e dados do sensor TM/Landsat. Revista Brasileira de Engenharia Agrícola e Ambiental 6, 492-498.
Allen, R.G., Tasumi, M., Trezza, R., 2007. SatelliteBased energy balance for mapping evapotranspiration with internalized calibration (METRIC) - Model. Journal of Irrigation and Drainage Engineering 133, 380-394.

Allen, R., Tasumi, M., Trezza, R., Waters, R., Bastiaanssen, W., 2002. SEBAL: Surface Energy Balance Algorithms for Land, Idaho implementation. Waters Consulting, University of Idaho, Water Watch, Idaho. (Advanced Training and Users Manual, version 1.0).

Alvares, C.A., Stape, J.L., Sentelhas, P.C., Moraes, G., Leonardo, J., Sparovek, G., 2013. Köppen's climate classification map for Brazil. Meteorologische Zeitschrift 22, 711-728.

Arraes, F.D.D., Andrade, E.M., Silva, B.B., 2012. Dinâmica do balanço de energia sobre o açude Orós e suas adjacências. Revista Caatinga 25, 119-127.

Bastiaanssen, W.G.M., 2000. SEBAL - Based Sensible and Latent Heat Fluxes in the Irrigated Gediz Basin, Turkey. Journal of Hydrology 229, $87-100$.

Bastiaanssen, W.G.M., Noordman, E.J.M., Pelgrum, H., Davids, G., Thoreson, B.P., Allen, R.G., 2005. SEBAL model with remotely sensed data to improve water resources management under actual field conditions. Journal of Irrigation and Drainage Engineering 131, 85-93.

Bastiaanssen, W.G.M., Pelgrum, H., Wang, J., MA, Y., Moreno, J.F., Roerink, G.J., Van Der Wal, T., 1998a. A remote sensing surface energy balance algorithm for land (SEBAL) 1. Formulation. Journal of Hydrology 212-213, 198-212.

Bastiaanssen, W.G.M., Menenti, M., Feddes, R.A., Holtslag, A.A.M., 1998b. A remote sensing surface energy balance algorithm for land (SEBAL) 2. Validation. Journal of Hydrology 212-213, 213-229.

Bezerra, J.M., Moura, G.B.A., Silva, B.B., Lopes, P.M.O., Silva, E.F.F., 2014. Parâmetros biofísicos obtidos por sensoriamento remoto em região semiárida do estado do Rio Grande do Norte, Brasil1. Revista Brasileira de Engenharia Agrícola e Ambiental, 18, 73-84.

Chander, G., Markham, B.L.; Helder, D.L., 2009. Summary of current radiometric calibration coefficients for Landsat MSS, TM, ETM+, and EO-1 ALI sensors. Remote Sensing of Environment 113, 893-903.

Fausto, M.A., Machado, N.G., Nogueira, J.S., Biudes, M.S., 2014. Net radiation estimated by remote sensing in Cerrado areas in the Upper Paraguay River Basin. Journal of Applied Remote Sensing 8, 1-17.

Felde, G.W., Anderson, G.P., Cooley, T.W., Matthew, M.W., Adler, G.S.M., Berk, A., Lee, J., 
2003. Analysis of Hyperion data with the FLAASH atmospheric correction algorithm. IEEE International Geoscience and Remote Sensing Symposium, 1, 90-92.

Gutiérrez, A.P.A., Engle, N.L., De Nys, E., Molejón, C., Martins, E.S., 2014. Drought preparedness in Brazil. Weather and Climate Extremes 3, 95-106.

Huete, A.R., 1988. A soil adjusted vegetation index (SAVI). Remote Sensing of Environment 25, 295309.

Iqbal, M., 1983. An Introduction to Solar Radiation. Academic Press., London.

Kachhwala, T.S., 1985. Temporal monitoring of forest land for change detection and forest cover mapping through satellite remote sensing. Asian Conference on Remote Sensing. Hyderabad.

Marengo, J.A., Alves, L.M., Alvala, R., Cunha, A.P., Brito, S., Moraes, O.L., 2018. Climatic characteristics of the 2010-2016 drought in the semiarid Northeast Brazil region. Anais da Academia Brasileira de Ciências 90, 1973-1985.

Marengo, J.A., Torres, R.R., Alves, L.M., 2016. Drought in Northeast Brazil-past, present, and future. Theoretical and Applied Climatology 129, 1189-1200.

Mariano, D.A., Santos, C.A., Wardlow, B.D., Anderson, M.C., Schiltmeyer, A.V., Tadesse, T., Svoboda, M.D., 2018. Use of remote sensing indicators to assess effects of drought and humaninduced land degradation on ecosystem health in Northeastern Brazil. Remote Sensing of Environment 213, 129-143.

NASA/USGS., 2019. National Aeronautics and Space Administration/United States Geological Survey. Using the USGS Landsat 8 Product. Available: https://landsat.usgs.gov/using-usgslandsat-8-product. Acess: aug. 9, 2019.

Nascimento, F.C.A., Araújo, F.R.C.D., Santos, C.A.C., Santos, E.G., 2014. Análise das mudanças ambientais provocadas pela expansão urbana na cidade de Mossoró-RN, através do uso de técnicas de Sensoriamento Remoto. Revista Brasileira de Geografia Física 7, 636-642.

Oliveira, L.M.M., Montenegro, S.M.G.L., Antonino, A.C.D., Silva, B.B., Machado, C.C.C., Galvíncio, J.D., 2012. Análise quantitativa de parâmetros biofísicos de bacia hidrográfica obtidos por sensoriamento remoto. Pesquisa Agropecuária Brasileira 47, 1209-1217.

Palácio, H.A.Q., Andrade, E.M., Santos, J.C.N.,
Araújo Neto, J.R., Brasil, P.P., 2013. Energy evaluation of semi-arid watersheds under different management strategies. Transactions of the ASABE 56, 1-7.

Rodrigues, J.D., Andrade, E.D., Teixeira, A.D.S., Silva, B.D., 2009. Sazonalidade de variáveis biofísicas em regiões semiáridas pelo emprego do sensoriamento remoto. Engenharia Agrícola 29, 452-465.

Silva, B.B., Lopes, G.M., Azevedo, P.V., 2005. Determinação do albedo de áreas irrigadas com base em imagens Landsat 5 TM. Revista Brasileira de Agrometeorologia 13, 201-211.

Silva, B.B.D., Braga, A.C., Braga, C.C., Oliveira, L.M., Montenegro, S.M., Barbosa Junior, B., 2016. Procedures for calculation of the albedo with OLI-Landsat 8 images: application to the Brazilian semi-arid. Revista Brasileira de Engenharia Agrícola e Ambiental 20, 3-8.

Silva, D.A.O., Lopes, P.M.O., Moura, G.B.A., França e Silva, E.F., Silva, J.L.B., Bezerra, A.C., 2019. Evolução Espaço-Temporal do Risco de Degradação da Cobertura Vegetal de PetrolinaPE. Revista Brasileira de Meteorologia 34, 1-11.

Silva, D.A.O., Silva, J.L.B., Oliveira, J.D.A., Batista, P.H.D., Lopes, P. M.O., Moura, G.B.A., 2018. Evolução espaço-temporal da vegetação em região semiárida, in: Francisco, P.R.M., Ribeiro, G.N., Silvino, G.S., Pereira, F.C., Moraes Neto, J.M., Silva, V.M.A. (Org.), Geotecnologias Aplicada à Estudos Ambientais. EPGRAF, Campina Grande, pp. 87-101.

Silva, L.G., Galvíncio, J.D., 2012. Análise comparativa da variação nos índices NDVI e SAVI no Sítio PELD - 22, em Petrolina - PE, na primeira década do século XXI. Revista Brasileira de Geografia Física 5, 1446-1456.

Souza, J.F., 2014. Análise das mudanças do uso e ocupação do solo, variabilidade da temperatura e do saldo de radiação em João Pessoa-PB. Dissertação (Mestrado). João Pessoa, UFPB.

Turner, M.G., Ruscher, C.L., 2004. Change in landscape patterns in Georgia. USA Landscape Ecology 1, 251-421.

Yuan, F., Sawaya, K.E., Loeffelholz, B.C., Bauer, M.E., 2005. Land cover classification and change analysis of the Twin Cities (Minnesota) Metropolitan Area by multitemporal Landsat remote sensing. Remote Sensing of Environment 98, 317-328. 